Crisis in the Eurozone 
Also by Mark Baimbridge

FROM ROME TO MAASTRICHT: A Reappraisal of Britain's Membership of the European Community

THERE IS AN ALTERNATIVE: Britain and Its Relationship with the EU THE IMPACT OF THE EURO: Debating Britain's Future

ECONOMIC AND MONETARY UNION IN EUROPE: Theory, Evidence and Practice FISCAL FEDERALISM AND EUROPEAN ECONOMIC INTEGRATION CURRENT ECONOMIC ISSUES IN EU INTEGRATION BRITAIN AND THE EUROPEAN UNION: Alternative Futures IMPLICATIONS OF THE EURO: A Critical Perspective from the Left THE 1975 REFERENDUM ON EUROPE: Current Analysis and Lessons for the Future THE 1975 REFERENDUM ON EUROPE: Reflections of the Participants BRITAIN, THE EURO, AND BEYOND

BRITAIN IN A GLOBAL WORLD: Options for a New Beginning MOORED TO THE CONTINENT? Future Options for Britain and the EU THE POLITICAL ECONOMY OF THE EUROPEAN SOCIAL MODEL

Also by Philip B. Whyman

THERE IS AN ALTERNATIVE: Britain and Its Relationship with the EU THE IMPACT OF THE EURO: Debating Britain's Future ECONOMIC AND MONETARY UNION IN EUROPE: Theory, Evidence and Practice FISCAL FEDERALISM AND EUROPEAN ECONOMIC INTEGRATION SWEDEN AND THE 'THIRD WAY': A Macroeconomic Evaluation AN ANALYSIS OF THE ECONOMIC DEMOCRACY REFORMS IN SWEDEN BRITAIN AND THE EUROPEAN UNION: Alternative Futures IMPLICATIONS OF THE EURO: A Critical Perspective from the Left THIRD WAY ECONOMICS: An Evaluation

THE 1975 REFERENDUM ON EUROPE: Current Analysis and Lessons for the Future BRITAIN, THE EURO AND BEYOND

BRITAIN IN A GLOBAL WORLD: Options for a New Beginning MOORED TO THE CONTINENT? Future Options for Britain and the EU THE POLITICAL ECONOMY OF THE EUROPEAN SOCIAL MODEL 


\title{
Crisis in the Eurozone
}

\section{Causes, Dilemmas and Solutions}

\author{
Mark Baimbridge
}

University of Bradford, UK

Philip B. Whyman

University of Central Lancashire, UK

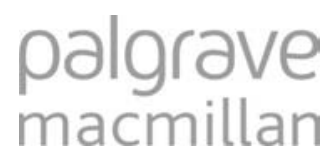




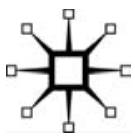

(C) Mark Baimbridge and Philip B. Whyman 2015

Softcover reprint of the hardcover 1st edition 2015 978-1-137-32902-8

All rights reserved. No reproduction, copy or transmission of this publication may be made without written permission.

No portion of this publication may be reproduced, copied or transmitted save with written permission or in accordance with the provisions of the Copyright, Designs and Patents Act 1988, or under the terms of any licence permitting limited copying issued by the Copyright Licensing Agency, Saffron House, 6-10 Kirby Street, London EC1N 8TS.

Any person who does any unauthorized act in relation to this publication may be liable to criminal prosecution and civil claims for damages.

The authors have asserted their rights to be identified as the authors of this work in accordance with the Copyright, Designs and Patents Act 1988.

First published 2015 by

PALGRAVE MACMILLAN

Palgrave Macmillan in the UK is an imprint of Macmillan Publishers Limited, registered in England, company number 785998, of Houndmills, Basingstoke, Hampshire RG21 6XS.

Palgrave Macmillan in the US is a division of St Martin's Press LLC, 175 Fifth Avenue, New York, NY 10010.

Palgrave Macmillan is the global academic imprint of the above companies and has companies and representatives throughout the world.

Palgrave ${ }^{\circledR}$ and Macmillan ${ }^{\circledR}$ are registered trademarks in the United States, the United Kingdom, Europe and other countries

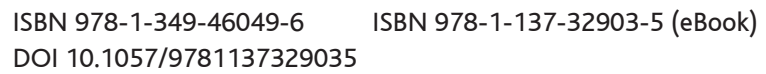

This book is printed on paper suitable for recycling and made from fully managed and sustained forest sources. Logging, pulping and manufacturing processes are expected to conform to the environmental regulations of the country of origin.

A catalogue record for this book is available from the British Library.

Library of Congress Cataloging-in-Publication Data

Baimbridge, Mark.

Crisis in the eurozone : causes, dilemmas and solutions / Mark Baimbridge, University of Bradford, UK, Philip B. Whyman, University of Central Lancashire, UK.

pages $\mathrm{cm}$

ISBN 978-1-349-46049-6

1. Financial crises - European Union countries. 2. Eurozone. 3. Monetary policy - European Union countries. 4. European Union countriesEconomic conditions - 21st century. I. Whyman, Philip. II. Title. HB3782.B347 2015 


\section{Contents}

List of Illustrations vi

Acknowledgements vii

European Integration Timeline viii

Chronology of Eurozone Crisis xiii

Glossary of Terms $\quad$ xxi

1 The Eurozone as a Flawed Currency Area 1

\section{Part I The Economics of Monetary Integration}

2 The Development of Microfoundations of Macroeconomics

3 Contemporary Macroeconomic Thought and Its Discontents $\quad 40$

4 Theoretical Considerations of a Single Currency 55

\section{Part II Contemporary Economic Policymaking}

5 Rules and Institutions in International Monetary Systems 73

6 Fiscal Policy within the Eurozone 88

7 Monetary Policy within the Eurozone 106

8 Economic Policymaking within the Eurozone 121

\section{Part III Solutions to the Eurozone Crisis}

9 Moral Suasion, Financial Relief and Debt Default 139

10 Fiscal Federalism 156

11 European Clearing Union $\quad 171$

12 The Collapse of the Eurozone: Disaster or Liberation? 186

13 From the Eurozone to National Economic Self-Governance 202

$\begin{array}{ll}\text { Bibliography } & 215\end{array}$

$\begin{array}{ll}\text { Index } & 253\end{array}$ 


\section{List of Illustrations}

\section{Figures}

1.1 Current account balance (\% of GDP) for eurozone members 1992-2013

6.1 Budget balance to GDP (1981-2008)

6.2 Country average for budget balance to GDP (1981-2008) 100

6.3 Percentage of public debt to GDP (1981-2008) 102

6.4 Attainment of convergence criteria by the EU15 103

8.1 Economic policymaking within the Eurozone 128

8.2 Lag structure in the IS-PC-MR model required to deliver a Taylor Rule

\section{Tables}

1.1 Mean GDP growth rates 3

1.2 Mean unemployment rate 4

2.1 Fiscal and prudent rules in industrialised economies 36

6.1 Fiscal positions in year of entering the eurozone 101

6.2 Percentage-point change in public debt (1981-2008) 102

7.1 Political independence of central banks 113

7.2 Economic independence of central banks 114

7.3 Comparison of central bank independence of EU member states and the ECB

12.1 Comparison between features of Post-Keynesianism and the eurozone 


\section{Acknowledgements}

There are many people to thank for their input in making this book possible. Most obviously, we must thank our commissioning editor at Palgrave Macmillan, Taiba Batool, for her support for this project and Ania Wronski (editorial assistant) for her very enduring patience. Second, we are grateful to several students; in particular, Zhang He, Jessica Carswell and Saba Javed, who have provided inspiration for aspects of the book. Third, we would like to thank our long-time colleague Brian Burkitt, together with those at the universities of Bradford and Central Lancashire, for their comradeship and general support for our research on European economic integration. Finally, we owe a deep sense of gratitude to our families for their forbearance during the preparation of this book. It is to them that this book is dedicated: M.B.: Mary, Beibei and Douglas; P.W.: Barbara, Boyd and Claire.

Any remaining errors and omissions we gladly attribute to each other.

Haworth and Heaton Norris June 2014 


\section{European Integration Timeline}

1948 The Organisation for European Economic Cooperation (OEEC) is set up in Paris in April 1948, coordinating the distribution of the Marshall Plan financial aid, which will amount to $\$ 12.5$ billion from 1948 to 1951. The OEEC consists of one representative from each of the 17 Western European countries that join the organisation. In May 1948, in The Hague, the Congress of Europe (a meeting of delegates from 16 European countries) agree to form the Council of Europe with the aim of establishing closer economic and social ties.

1951 The European Coal and Steel Community (ECSC) is established by the signing of the Treaty of Paris in April 1951. Along with France and West Germany, Italy, Belgium, Luxembourg and The Netherlands have also chosen to join the organisation. Members of the ECSC pledge to remove all import duties and quota restrictions on the trade of coal, iron ore, and steel between the member states.

1952 The European Defence Community (EDC) Treaty is signed by France, West Germany, Italy, Belgium, Holland and Luxembourg in May 1952. It includes the provision for the formation of a parallel European Political Community (EPC). However, both initiatives are destined to founder since the French National Assembly never ratifies the EDC Treaty, finally rejecting it in August 1954.

1955 The process of further European integration is given fresh impetus by a conference of ECSC foreign ministers at Messina, Italy, in June 1955. The meeting agrees to develop the community by encouraging free trade between member states through the removal of tariffs and quotas. Agreement is also reached to form an Atomic Energy Community to encourage cooperation in the nuclear energy industry.

1958 The two Treaties of Rome are signed, establishing the European Economic Community (EEC) and the European Atomic Energy Community (Euratom). As well as stipulating the eventual removal of customs duties on trade between member countries (over a period of 12 years) the EEC Treaty sets out to allow the free movement of workers, capital and services across borders and to harmonise policies on agriculture and transport.

1960 At the Stockholm Convention in January 1960, Austria, Britain, Denmark, Norway, Portugal, Sweden and Switzerland form the 
European Free Trade Association (EFTA). The objective of EFTA is to promote free trade but without the formal structures of the EEC.

1961 UK applies to join the EEC.

1963 British application for EEC membership fails.

1967 UK submits second application to join EEC.

1968 Customs union completed and Common Agricultural Policy enacted.

1972 In October, following the recommendations of the Werner Report, the EEC launches its first attempt at harmonising exchange rates. The mechanism adopted is the so called 'snake in the tunnel', whereby participating governments are required to confine the fluctuations of their currencies within a range of $+/-1 \%$ against each other. The value of the group of currencies (the snake) is also to be maintained within a range of $+/-2.25 \%$ against the U.S. dollar (the tunnel). Countries requiring assistance to keep their currencies within the required band may receive help only in the form of loans.

1973 Denmark, Ireland and the UK join the EEC.

1975 UK referendum supports staying in EEC.

1978 At a summit in Bremen in July, the French and West German governments announce their intention to create the European Monetary System (EMS). At the centre of the EMS is the European Currency Unit (ECU). The value of the ECU is to be derived from a weighted basket of all participating currencies with the greatest weighting against the West German mark.

1981 Greece joins the EC.

1986 Portugal and Spain join the EC.

1990 UK joins EMS.

1992 At a summit of the European Council in Maastricht, Holland, the Treaty on European Union (TEU), also known as the Maastricht Treaty, is signed. Originally intended to include a declaration of an intention to move towards federal union, at Britain's insistence this aspect is played down. Subsequent to the signing of the Maastricht Treaty, the European Community is referred to as the European Union (EU). UK leaves EMS.

1993 The Single European Market takes effect. Trade tariffs are scrapped, but duty-free shopping remains until 1999.

1994 Stage 2 of EMU is initiated on January 1st with the establishment of the European Monetary Institute (EMI) to oversee the co-ordination of the monetary policies of the individual national central banks. The EMI will also work towards the introduction of stage 3 by organising the creation of the European Central Bank. 
1995 Austria, Finland and Sweden join the EU, bringing membership to 15 .

The Schengen Agreement comes into force and scraps border controls. UK and Ireland stay out of the agreement.

1997 Heads of government draft a new agreement in Amsterdam which updates the Maastricht Treaty and prepares the EU for its eastward expansion. Qualified majority voting is introduced into new areas, reducing individual countries' powers to veto new measures.

1998 At the beginning of May, at a summit of EU officials and heads of state in Brussels, the announcement is made as to which countries will participate in the launch of the euro the following January. In June the European Central Bank (ECB) is established in Frankfurt, Germany. The ECB together with the national central banks of the 15 EU member states form the European System of Central Banks (ESCB), which will be responsible for setting monetary policy for the euro countries and managing those countries' foreign reserves.

The EU opens accession negotiations with Hungary, Poland, Estonia, the Czech Republic, Slovenia and Cyprus.

1999 Romania, Slovakia, Latvia, Lithuania, Bulgaria and Malta are invited to begin accession negotiations.

Eleven countries adopt the euro as their official currency (although national currency notes and coins remain in circulation), but Sweden, Denmark and the UK stay out.

2000 The Nice summit agrees to limit the size of the Commission and increase the president's powers. Qualified majority voting is introduced in new areas, but members keep their vetoes on social security and tax. A timetable for taking forward accession negotiations is endorsed.

2001 The Laeken European Council establishes the Convention on the Future of Europe.

2002 Euro notes and coins are introduced in 12 EU countries.

The European Commission announces that ten countries are on course to meet the criteria for accession to the EU in 2004.

2003 The UK has been a member of the EU for 30 years.

2004 EU enlargement to 25 member states with addition of Slovakia, Latvia, Lithuania, Malta, Hungary, Poland, Estonia, the Czech Republic, Slovenia and Cyprus.

2005 EU Constitution ratification ended by referendum defeats in France and the Netherlands.

The UK holds EU presidency, but fails to make progress on new 2007-2013 budget.

Accession negotiations are opened with Turkey and Croatia.

2006 Slovenia's entry into the euro on 1 January 2007 is confirmed. 
Accession negotiations with Turkey are suspended.

2007 EU enlargement to 27 member states with addition of Bulgaria and Romania.

2008 Slovenia becomes the first of the recent enlargement member to hold the presidency of the Council of the EU.

Treaty of Lisbon ratification ended by referendum defeat in Ireland.

2009 Final year of the Barroso Commission.

Seventh series of elections to the European Parliament.

Second referendum on the Treaty of Lisbon in Ireland.

2010 Spain is the first country to hold the Presidency of the Council of the EU under the Lisbon Treaty and the new 'trio presidency system' with Belgium and Hungary.

Heads of state and government agree to support the Greek government in its efforts to meet the Stability Programme targets for 2010.

European Council adopts a ten-year strategy for smart, sustainable and inclusive growth: Europe 2020.

The EU agrees to support the Irish economy to help safeguard the stability of the euro.

2011 Estonia adopts the euro, becoming the seventeenth member of the euro area.

The first 'European semester' of economic policy coordination between EU countries to help prevent economic crises like the one in 2008-2010.

A comprehensive package of measures to strengthen the European economy is finalised with the Euro Plus Pact to reinforce economic policy coordination in the EMU.

Three new European financial supervisory authorities begin operating: the European Banking Authority, the European Insurance and Occupational Pensions Authority and the European Securities and Markets Authority.

European Council agrees that the accession negotiations with Croatia should be concluded by the end of June 2011, paving the way for the country to become the twenty-eighth EU member in 2013.

The EU seeks to resolve the eurozone crisis centered on Greece through establishing the European Financial Stability Facility (EFSF) to become the European Stability Mechanism (ESM) from 2013.

2012 Denmark takes over the six-month rotating presidency of the Council.

Croatia vote 'yes' by 66 to $33 \%$ in its accession referendum and so will become the twenty-eighth EU member on 1 July 2013. 
The European Council proposes a new treaty on stability, coordination and governance in the economic and monetary union, which is agreed by all EU countries with the exception of the Czech Republic and the UK.

A treaty to create a European Stability Mechanism (ESM) is signed.

The European Council grants candidate status to Serbia.

The European Citizens' Initiative becomes a reality, enabling citizens to propose EU legislation on specific issues for the first time. As part of the 'European Semester', the Commission adopts recommendations for each member state, offering guidance on 20122013 national budgets and economic policies.

Cyprus takes over the six-month rotating presidency of the Council.

The European Stability Mechanism (ESM) enters into force.

The European Union is awarded the Nobel Peace Prize 2012.

2013 Ireland takes over the six-month rotating presidency of the Council.

The Treaty on Stability, Coordination and Governance in the Economic and Monetary Union enters into force.

Croatia joins the EU, bringing the total number of member countries to 28 .

Lithuania takes over the six-month rotating presidency of the Council.

2014 Greece takes over the six-month rotating presidency of the Council.

Latvia adopts the euro as its currency, becoming the eighteenth member of the euro area.

The European Parliament adopts a set of rulebooks on how to deal with banks in serious difficulties, as the final element of the EU's Banking Union. 


\section{Chronology of Eurozone Crisis}

1970 EC Commission resolution to establish Economic and Monetary Union (EMU). Werner Committee Report on EMU issued.

1973 Collapse of 'snake in the tunnel' policy.

1977 European Monetary System (EMS) launched.

1979 EMS comes into operation.

1991 European Council meeting in Maastricht agrees the Treaty on European Union.

1992 Crisis in the ERM leading to the UK and Italy suspending their memberships.

1998 European Council decides that $11 \mathrm{EU}$ member states will participate when the euro is launched in 1999 (France, Germany, Italy, Belgium, Luxembourg, the Netherlands, Ireland, Spain, Portugal, Finland and Austria).

1999 Exchange rate parities of the participating member states and their conversion rates into euros are irrevocably fixed. The euro becomes a currency in its own right. Member states' monetary policy, exchange-rate policy carried out, and new public-sector debt instruments issued, in euros. The ESCB, national and EU public authorities to oversee and assist with currency changeover.

2001 Greece is added to list of eurozone member states.

2002 Euro banknotes and coins to circulate alongside national currency notes and coins.

2007 January: Slovenia joins the euro.

2008 January: Malta and Cyprus join the euro. EU leaders agree on a $€ 200$ bn stimulus plan to help boost European growth following the global financial crisis.

2009 January: Slovakia joins the euro. Estonia, Denmark, Latvia and Lithuania join the Exchange Rate Mechanism (ERM) to bring their currencies and monetary policy into line with the euro in preparation for joining. The EU orders France, Spain, the Irish Republic and Greece to reduce their budget deficits.

April: Standard and Poor's downgrades Greece's debt ratings below investment-grade to junk-bond status; downgrades Portuguese debt two notches and issues negative outlook; downgrades Spanish bonds.

October: Amid much anger in Greece towards the previous government over corruption and spending, George Papandreou's Socialists win a general election. 
December: Greece admits that its debts have reached $€ 300 \mathrm{bn}$, the highest in modern history, such that it is burdened with debt amounting to $113 \%$ of GDP.

2010 January: An EU report condemns 'severe irregularities' in Greek accounting procedures. Greece's budget deficit in 2009 is revised upwards to $12.7 \%$, from $3.7 \%$, and more than four times the maximum allowed by EU rules. The ECB dismisses speculation that Greece will have to leave the EU. Greece unveils a series of austerity measures aimed at curbing the deficit from $12.7 \%$ in 2009 to $2.8 \%$ in 2012 .

March: The eurozone and IMF agree a safety net of €22bn to help Greece, raised to €30bn in April. Papandreou continues to insist that no bailout is needed. ECB extends softer rules on collateral to avoid a situation where one ratings agency decides if a eurozone country's bonds are eligible for use as ECB collateral.

April: The EU announces that the Greek deficit is even worse than thought at $13.6 \%$ of GDP, not $12.7 \%$.

May: The ECB announces that it will accept Greek government bonds as collateral no matter what their rating is. The eurozone members and the IMF agree a €110bn bailout package to rescue Greece. Ireland's debt starts to come under scrutiny.

June: The EU releases the results of 'stress tests' conducted on 91 European financial institutions, with seven failing to maintain the minimum amount of ready capital required by examiners.

September: EU finance ministers and IMF approve second of the bailout instalments for Greece of $€ 6.5 \mathrm{bn}$ and $€ 2.57 \mathrm{bn}$ respectively. Ireland's central bank announces that the cost of bailing out Anglo Irish Bank could reach as much as $€ 34$.3bn, pushing its budget deficit to $32 \%$ of GDP.

November: Ireland starts talks and then accepts an €85bn package to help alleviate its debt burden, contrary to previous denials that it would need external help. Ireland then passes an austerity budget.

2011 January: Estonia joins the euro. Fitch becomes the third ratings agency to cut Greek debt to 'junk' status after S\&P and Moody's.

February: Eurozone finance ministers set up a permanent bailout fund, the European Stability Mechanism (ESM), of €500bn.

May: The eurozone and IMF approve a €78bn bailout for Portugal. June: Eurozone ministers say Greece must impose new austerity measures before it gets the next tranche of its loan, without which the country will probably default on its debts. Standard \& Poor's downgrades Greece's credit rating, making it the country with the world's lowest-rated sovereign debt. 
July: A second bailout for Greece is agreed. The eurozone agrees a comprehensive €109bn package designed to resolve the Greek crisis and prevent contagion among other European economies. The Greek parliament votes in favour of a fresh round of austerity measures; the EU approves the latest tranche of the Greek loan of $€ 12 \mathrm{bn}$.

August: Interest rates on ten-year Italian government bonds top $6 \%$ as confidence in the coalition led by Prime Minister Silvio Berlusconi is undermined by personal scandals and his on-going disagreements with Finance Minister Giulio Tremonti. Italy's $€ 1.9$ tr public debt falls under increasing scrutiny from investors and, at $120 \%$ of GDP, Italy's rate of indebtedness is second only to Greece. The ECB says it will buy Italian and Spanish government bonds to try to bring down their borrowing costs, as concern grows that the debt crisis may spread to the larger economies of Italy and Spain. September: A meeting of finance ministers and central bankers in Washington leads to more calls for urgent action, but a lack of concrete proposals sparks further falls in share markets. Greece holds 'productive and substantive' talks with its international supporters, the European Central Bank, European Commission and IMF. Spain passes a constitutional amendment to add in a 'golden rule,' keeping future budget deficits to a strict limit. Italy's legislature approves a €54bn austerity package with the intention of wiping out Italy's budget deficit by 2013, but Italy has its debt rating cut by $S \& P$.

October: The Bank of England injects a further $£ 75 \mathrm{bn}$ into the UK economy through quantitative easing, while the ECB unveils emergency loan measures to help banks. European leaders reach a 'three-pronged' agreement described as vital to solve the region's huge debt crisis. Some private banks holding Greek debt have accepted a loss of 50\%. Banks must also raise more capital to protect themselves against losses resulting from any future government defaults. Slovakia's coalition government collapses when Prime Minister Iveta Radičová ties her country's approval of the expansion of the EFSF (requiring unanimous consent of all eurozone members) to a confidence motion. Eurozone finance ministers approve the next $€ 8$ bn tranche of Greek bailout loans, potentially saving the country from default.

November: Summit of G20 leaders discusses the eurozone crisis, and European leaders publicly declare that Greece's departure from the single currency is a possibility. Prime Minister Papandreou announces a Greek referendum on the new eurozone debt deal, but then withdraws promised referendum amid heavy pressure from Germany and France. Papandreou responds by abandoning 
the planned referendum. Spain becomes the third eurozone country in three weeks to see a change in government. Spanish voters sweep the ruling Spanish Socialist Workers' Party (PSOE) from power, handing the Popular Party (PP) an overall majority in parliament. Zapatero remains caretaker prime minister while PP leader Mariano Rajoy begins the task of forming a new government. Berlusconi's budget passes, and he resigns to be replaced by Mario Monti, a politically independent economist who previously served on the European Commission. S\&P downgrades Belgium's long-term sovereign credit ratings.

December: All eurozone members and six countries that aspire to join agree on a new intergovernmental treaty (a fiscal stability union) to cap government spending and borrowing, with penalties for those countries that violate the limits. All other non-eurozone countries, except the UK, are also prepared to join in. The ECB starts the biggest infusion of credit into the European banking system by loaning $€ 489$ bn to 523 banks at a rate of just $1 \%$ over a three-year period. In Greece a new interim national union government led by Lucas Papademos (former ECB vice-president) submits its plans for the 2012 budget, promising to cut its deficit from 9\% of GDP 2011 to 5.4\% in 2012; however, both Fitch and Moody's cuts Greece's rating, with a negative outlook.

2012 January: The 'fiscal pact' initially proposed in December 2001, containing for new rules that make it harder to break budget deficits, is signed by 25 EU members, with the UK and the Czech Republic opting-out. Talks stall between Greece and its private creditors over a debt write-off deal. The deal is necessary if Greece is to receive the bailout funds it needs to repay billions of euros of debt in March. Standard \& Poor's downgrades France and eight other eurozone countries, together with the EFSF blaming the failure of eurozone leaders to deal with the debt crisis.

February: The ECB holds a second auction, providing 800 Eurozone banks with further $€ 529.5 \mathrm{bn}$ in loans. Following negotiations with private lenders and the EU/IMF/ECB troika as Greece tries to get a debt write-off and make even more spending cuts to get its second bailout, its coalition government finally agrees to pass the demands made of it by international lenders. But the eurozone effectively casts doubt on the figures, requiring a further $€ 325 \mathrm{~m}$ in budget cuts.

March: 25 EU countries sign the new pact on fiscal discipline. While it will be binding only for those countries that use the euro, other signatories can choose to abide by its guidelines. However, unlike previous EU treaties, unanimous support from member countries is not required, and the agreement enters into force 
upon ratification by 12 of the 17 eurozone countries. Eurozone finance ministers announce an expansion of the EFSF and ESM to a combined $€ 800 \mathrm{bn}$ in funding. This increase is made at the urging of the G20 and the IMF, who had expressed concern that the existing rescue funds were not sufficient to manage the bailout of a country such as Spain or Italy. The government of Prime Minister Mariano Rajoy unveils a budget that cuts some €27bn in spending, intended to bring Spain back into line with the new EU fiscal pact. The eurozone governments and IMF finally back a second Greek bailout of $€ 130 \mathrm{bn}$. With a majority of private bondholders agreeing to swap their existing Greek government bonds for ones with a longer term, a lower interest rate and less than half the previous face value, the Greek government exercises 'collective action clauses' to force the remaining bondholders to accept the deal. The action allows Greece to erase some €100bn in government debt. Unlike the 'selective default' of July 2011 the activation of the collective action clauses marks the event as a true loan default. The International Swaps and Derivatives Association declares that a 'credit event' has occurred, a decision that triggers the payout of credit-default swap insurance.

April: Spanish shares hit by worries over the country's economy, and the Spanish government's ten-year cost of borrowing rose back towards $6 \%$, signalling fear over the country's creditworthiness. Italian borrowing costs increase in a sign of fresh concerns among investors about the country's ability to reduce its high levels of debt. In an auction of three-year bonds, Italy pays an interest rate of $3.89 \%$, up from $2.76 \%$ in a sale of similar bonds the previous month.

May: The European Commission adopts a package of recommendations for budgetary measures and economic reforms and recommends that the euro area make steps towards a 'full economic and monetary union', including a banking union, integrated supervision and a common deposit insurance scheme. Spain's fourth largest bank, Bankia, is effectively nationalised as the government announces a $€ 23.5 \mathrm{bn}$ bailout. A majority of Greeks vote in a general election for parties that reject the country's bailout agreement. Market analysts begin to discuss a 'Grexit', so capital flight becomes a growing concern as depositors fear a possible return to the drachma. Greece agrees to repay in full a €435m bond after previously declaring that it would default on any investors that did not participate in its €206bn debt swap. It is reported that depositors withdrew $€ 700 \mathrm{~m}$ from banks, sparking fears of a bank run.

June: EU leaders' meeting is dominated by Rajoy and Monti, who secure more-favourable lending terms, and eurozone leaders 
agree that countries obtaining loans from the ESM will not be subject to troika oversight. Additionally, steps are taken to establish a eurozone banking union, with supervisory powers vested in the ECB. The European Council adopts a 'growth compact' and tasks the president of the European Council, the president of the Commission, the president of the Eurogroup and the president of the ECB (the 'Four Presidents') with developing a specific, time-bound roadmap for the achievement of a genuine eurozone. In Greece, new elections held after attempts to form a coalition government fail. The pro-austerity party, New Democracy, wins most votes, allaying fears about Greece leaving the eurozone. In an effort to shore up its undercapitalised banking sector, Cyprus becomes the fifth eurozone country to apply for a bailout (€4bn). After emergency talks Economy Minister Luis de Guindos of Spain says that the country will shortly make a formal request for up to $€ 100 \mathrm{bn}$ in loans from eurozone funds to try to help shore up its banks. Although Prime Minister Rajoy characterises the transaction as a 'soft loan' rather than a bailout, EU officials emphasise that the troika will oversee both the loan and any conditions that might be attached to it.

July: The ECB drops a key interest rate to $0.75 \%$, which lowers the cost of borrowing for banks in the eurozone. Representatives of the troika arrive to investigate Cyprus's financial problems and submit bailout terms. The Cypriot government expresses disagreement over the terms. EU regulators agree to €18bn in aid for four Greek banks (Alpha Bank AE, EFG Eurobank Ergasias SA, Piraeus Bank SA, and National Bank of Greece SA). Prime Minister Rajoy of Spain announces an austerity budget that includes some $€ 65 \mathrm{bn}$ in additional spending cuts and tax increases. Eurozone finance ministers agree to a plan for Spain's €100bn bank bailout plan. It is expected that the first €30bn will be delivered by the end of July. August: Catalonia becomes the third Spanish region to ask the nation's central government for a $€ 5$ bn bailout. The region faces $€ 5$.6bn of further bond maturities in 2012.

September: The ECB announces it would launch an unlimited but sterilised bond-buying program that would offset bond purchases by taking money out of circulation to avoid increasing the money supply. The new program known as Outright Monetary Transactions will replace the Securities Markets Program. Spaniards withdrew a record $€ 75$ bn from Spanish banks in July, equivalent to 7\% of GDP. The IMF approves a new €920m tranche for Ireland, the latest in financial aid that started in 2010.

October: The EU discusses the completion of EMU on the basis of an interim report presented by Herman Van Rompuy and agrees to 
have the legal framework for the single supervisory mechanism in place by January 2013. This agreement clears the way for the ESM to directly recapitalise banks, rather than having to act through national governments. It is hoped that this will break the vicious cycle of interconnected sovereigns and their systemically important banks. The Greek government submits its 2013 budget draft. The plan outlines further austerity measures of around €8bn, designed to placate the nation's lenders.

November: EU leaders fail to reach a deal on a common budget for its 27 members. A delay is expected until early 2013. EU Commission president, Barroso, says that he supports the 17-member eurozone nations integrating their economies faster than the wider, 27-member EU to facilitate a unified budget and the ability to issue eurozone-wide bonds. However, the Eurogroup approves a twoyear extension to Greece's fiscal-adjustment period. The IMF and eurozone reach a debt-reduction agreement for Greece amounting to $€ 40 \mathrm{bn}$. The reduction is expected to help Greece re-emerge from its crippled state by 2020. Greece announces that it will borrow $€ 10-14 \mathrm{bn}$ to finance the repurchase of debt demanded under the new terms of its bailout agreement.

December: EU finance ministers announce that they have reached an agreement to form a banking union. A single banking regulator, the $\mathrm{ECB}$, is thought to be a key to resolving the crisis. Authority is granted to force troubled banks to close their doors and for bank capital ratios to be raised. Credit ratings are lowered for the EFSF and ESM by Moody's.

2013 March: The Eurogroup and troika agree a €10bn bailout with Cyprus (the fifth country to receive money from the EU-IMF); in return for Cyprus agreeing to close its second largest bank, the Cyprus Popular Bank (also known as Laiki Bank), levying all uninsured deposits there, and possibly around $40 \%$ of uninsured deposits in the Bank of Cyprus, many held by wealthy citizens of other countries who were using Cyprus as a tax haven. As part of the deal, a one-off bank deposit levy of $6.7 \%$ for deposits up to $€ 100,000$ and $9.9 \%$ for higher deposits, was announced on all domestic bank accounts. No insured deposit of $€ 100,000$ or less would be affected. Savers were to be compensated with shares in their banks and measures were put in place to prevent withdrawal or transfer of moneys representing the prescribed levy. However, when the final agreement was settled the idea of imposing any sort of deposit levy was dropped, as it was now possible instead to reach a mutual agreement with the Cypriot authorities accepting a direct closure of the most troubled Laiki Bank (with remaining good assets and deposits below $€ 100,000$ being saved and transferred 
to the Bank of Cyprus, while shareholder capital would be written off, and the uninsured deposits above €100,000, along with other creditor claims, would be lost to the degree being decided by how much the receivership subsequently can recover from liquidation of the remaining bad assets. As an extra safety measure, uninsured deposits above $€ 100,000$ in the Bank of Cyprus will also remain frozen until a recapitalisation has been implemented (with a possible imposed haircut if this is later deemed needed to reach the requirement for a 9\% tier-1 capital ratio). Italy's general election failed to deliver a clear majority in the Senate. The centre-left coalition led by Pier Luigi Bersani won a narrow majority in the Lower House, but the Five-Star Movement, led by anti-euro comedian Beppe Grillo, emerged as the largest single party in the lower house and the second-largest party in the Senate. Outgoing PM Mario Monti was the biggest loser, with his party getting less than $10 \%$ of votes in both houses.

April: After several inconclusive ballots in which neither Prodi nor Marini (nor anyone else) found a majority, Giorgio Napolitano accepts to stand for re-election as Italian president in the hope that this will lead to a resolution of the Italian political crisis. Subsequently, Bersani resigns as leader of the Democratic Party (PD) and is replaced by Matteo Renzi. Enrico Letta, deputy leader of the PD, is invited by the president to form a government, after enough support is found for his leadership.

June: During state visit to Japan, President François Hollande of France declares that the eurozone crisis is over.

July: The IMF warns that it may be forced to write off some Greek debt after identifying an $\$ 11$ bn 'black hole' in the finances.

August: The Eurozone is brought out of 18 -month recession by Germany and France, but Economic Commissioner Olli Rehn warns that the crisis is far from over as the eurozone reports $0.3 \%$ second-quarter growth.

December: Ireland leaves the EU/IMF bailout programme with government debt at $130.4 \%$ of GDP in 2013. Portugal also passes a bailout review of its economy.

2014 January: As foreign investor confidence in the country has been restored, Spain formally exits the EU/IMF bailout mechanism.

April: Greece returns to international capital markets, issuing bonds worth €3bn. 


\section{Glossary of Terms}

Asymmetric and symmetric external shocks External shocks refer to the impact upon the domestic economy generated by activities beyond the control of UK authorities, for example a sudden rise in oil prices or change in global demand for raw materials. If an external shock has a similar effect upon a given group of countries, it is said to be a symmetric shock since the policy response will be largely the same for all countries. Asymmetric shocks, alternatively, refer to those changes in the external environment that have significantly different effects upon different countries, requiring very different policy responses by each country in order to respond effectively.

Cyclical and structural convergence Economic convergence refers to potential eurozone participants becoming economically similar prior to membership. Cyclical convergence occurs when the business cycles of boom and recession become increasingly similar amongst participating economies, so that a recession in the UK would occur approximately at the same time as a comparable slow-down in Germany, rather than one or two years in advance as at present. Similarly, structural convergence refers to changes in industrial and financial structure of the participating economies, which have the effect of ensuring similar reactions to external forces over the long term.

Deflation/Reflation Deflation may be defined as a reduction in economic activity in the economy, which is associated with a sustained reduction in inflation, output and employment. Reflation refers to an increase in economic activity which stimulates output, employment and inflation in varying degrees.

Devaluation/revaluation/over-valuation Devaluation refers to a reduction in the value of a given exchange rate relative to other rates, whilst revaluation concerns the increase in the exchange rate. For example, if the exchange rate on a given day is $£ 1$ equals $\$ 1.67$, if the value of sterling increases so that $£ 1$ could now buy $\$ 2$ worth of goods, the value of the pound would be said to have appreciated, whereas if the value falls to perhaps $\$ 1.50$, sterling would be said to have fallen in value or devalued. Over-valuation refers to the circumstance wherein the value of sterling is so high that British exporters find it difficult to compete and this possibly leads to a trade deficit where more is imported than exported. Too high an over-valuation could lead to economic recession, as export companies reduce output and lay off workers. This then may spread to the remainder of the economy. 
Economic and Monetary Union (EMU) As a matter of definition, monetary union occurs when exchange rates are permanently and irrevocably fixed and may therefore precede the introduction of a single currency. However, the two terms are generally used interchangeably. Economic union involves a further transfer of macroeconomic policy to the federal level - particularly monetary policy, but typically also 'coordination' of fiscal policy within prescribed limits.

European Central Bank (ECB) The ECB supersedes national central banks in those EU nations participating in the eurozone. Based in Frankfurt, the ECB will be in sole charge of exchange-rate and monetary policy for all the eurozone countries, setting one common interest rate, which will apply irrespective of the particular needs of individual countries at any period of time. Its sole policy goal is to achieve price stability without a similar responsibility to assist employment creation or economic growth. Policy conflict between ECB and the wider economic responsibilities of individual governments is difficult to resolve since the ECB is beyond the control of both member states and the EU Commission.

European Economic Area (EEA) The EEA came into being on 1 January 1994, following an agreement between the European Free Trade Association (EFTA) and the EU. It was designed to allow EFTA countries to participate in the European SIM without having to join the EU. In an obligatory referendum, Switzerland's citizens chose not to participate in the EEA. Instead, the Swiss are linked to the EU by bilateral agreements, with a different content than that of the EEA agreement. Thus, the current members/contracting parties are three of the four EFTA states (Iceland, Liechtenstein and Norway) and the EU25. The EEA is based on four 'freedoms': the free movement of goods, persons, services and capital between the EEA countries. The non EU members of the EEA have agreed to enact legislation similar to that passed in the EU in the areas of social policy, consumer protection, environment, company law and statistics.

European Free Trade Association (EFTA) The EFTA was established on 3 May 1960 as an alternative for European states that were not allowed, or did not wish, to join the EU. The treaty was signed on 4 January 1960 in Stockholm by seven states (United Kingdom, Denmark, Norway, Sweden, Austria, Switzerland and Portugal). Finland became an associate member in 1961 (becoming a full member in 1986), whilst Iceland joined in 1970. The United Kingdom, Denmark and Ireland joined the EU in 1973, and hence ceased to be EFTA members, whilst Portugal left EFTA for the EU in 1986. Liechtenstein joined in 1991 (previously its interests in EFTA had been represented by Switzerland). Finally, Austria, Sweden and Finland joined the EU in 1995 and hence ceased to be EFTA members. Currently, only Iceland, Norway, Switzerland and Liechtenstein remain members of EFTA. The EFTA states have jointly concluded free-trade agreements with a number of countries worldwide. EFTA has the following institutions: the 
Secretariat, the EFTA Council, the EFTA Surveillance Authority, and the EFTA Court.

European Monetary Institute (EMI) The forerunner of the European Central Bank (ECB).

European System of Central Banks (ESCB) The central banks of all member states participating in the eurozone, which will act as subsidiaries of the ECB, implementing its policies.

European Union (EU) Formally the European Community (EC) and Common Market, the change of name occurred after ratification of the Maastricht Treaty, signifying a changed relationship between the 12 (now 25) participating nation states (called 'member states' in EU terminology), from a loose trading community towards a federal state encompassing one currency, a central bank and discussion of parallel moves towards political union.

Euro-X Committee A committee of those member states participating in the eurozone where discussions may include market-sensitive preferences for interest and exchange rates.

Excessive Deficit Procedure (EDP) The EDP is a feature of the Maastricht Treaty, whereby a budget deficit is deemed excessive if it exceeds $3 \%$ of GDP and if government debt exceeds 60\% of GDP.

Fiscal federalism Fiscal federalism involves a redistribution of resources from more-successful to weaker regions of a federal state or, in the case of the single currency, between regions or member states participating in the eurozone. In practice, fiscal federalism acts in a similar manner to regional transfers in a nation state, whereby it seeks to stabilise the entire eurozone by reducing inflationary pressure in booming areas and kick-starting recoveries in depressed areas through a transfer of tax revenue from the former into public expenditure (or a tax cut) in the latter. Fiscal federalism may, therefore, assist macroeconomic management, particularly due to the existence of regional spill-overs or externalities, thereby preventing individual regions from 'going it alone'. It may also aid social cohesion by acting as an interregional public insurance scheme, preventing 'unlucky' areas bearing a disproportionate financial burden.

Fiscal policy Fiscal policy refers to the interaction between government expenditure and taxation. Under the eurozone, fiscal policy will remain under the control of national economic authorities, although constrained by the TEU convergence criteria and Stability and Growth Pact rules.

G7/G8 An informal grouping of seven of the largest industrialised economies (United States, Canada, Germany, France, United Kingdom, Australia and Japan). On occasion Russia has been invited to participate in recent summits, giving rise to the G8.

Gold Standard A currency arrangement whereby the central bank is obliged to give a fixed amount of gold in exchange for its currency. If a number of countries all fix their currencies relative to gold, they must, 
by definition, fix their exchange rates amongst themselves. The gold standard that existed between the majority of the industrialised economies during the 30 years-or-so before the First World War, imposed certain rules upon participating economies, the most important of which being a distaste for 'debasing the currency' by devaluing. Moreover, a participating nation experiencing a balance-of-payments deficit would have to take corrective deflationary action, thus preferring external over internal balance. The increased international volatility caused by war conditions terminated the system and its replication in 1925 was disastrous for the United Kingdom as it occurred upon pre-First World War parities, which no longer represented the true economic balance between nations.

Gross Domestic Product (GDP)/Gross National Product (GNP) These are two methods of measuring the value of the total flow of goods and services produced by an economy over a specified period of time - usually a year. The difference between the two is that GNP equals GDP plus net income earned by domestic residents from overseas investments.

International Monetary Fund (IMF) Established in 1944, by 2004 the IMF counted 184 members. It is intended to encourage international co-operation in monetary matters and the removal of foreign-exchange restrictions. Members are required to contribute a quota calculated upon the basis of GDP, and its fund can then be utilised to help members over temporary balance of payments difficulties, although usually in parallel with adopting corrective economic policies, such as domestic deflation and devaluation, intended to stimulate exports and reduce imports.

Treaty on European Union Convergence Criteria Established by the Treaty on European Union to ensure economic convergence amongst potential participants prior to their entry to the eurozone, there are five criteria which each country must achieve before they are permitted to participate in the single currency. They are: (a) each country's rate of inflation must be no more than $1.5 \%$ above the average of the lowest three inflation rates in the EMS; (b) its long-term interest rates must be within $2 \%$ of the same three countries chosen for the previous condition; (c) it must have been a member of the narrow band of fluctuation of the ERM for at least two years without a realignment; (d) its budget deficit must not be regarded as 'excessive' by the European Council, with 'excessive' defined to be where deficits are greater than 3\% of GDP for reasons other than those of a 'temporary' or 'exceptional' nature; (e) its national debt must not be 'excessive', defined as where it is above $60 \%$ of GDP and is not declining at a 'satisfactory' pace.

Monetary policy Monetary policy is typically concerned with the level of interest rates, the availability of credit, banking regulations and the control of the money supply by the central bank. Under the eurozone, monetary policy will be transferred from national authorities to the ECB. 
Nominal and real-wage rigidity Nominal wages refer to money wages, whereas real wages refer to the purchasing power of those wages. Thus, a $3 \%$ rise in nominal wages during a period of $2 \%$ inflation produces a $1 \%$ rise in real wages. Wage rigidity refers to a situation in which wages are observed not to be perfectly flexible in response to a change in economic circumstances: for example, if wages should fail to fall sufficiently to price people back into work during a recession.

Non-accelerating inflation rate of unemployment (NAIRU) NAIRU is the rate of unemployment, whether it be $1 \%$ or $8 \%$, where inflation remains stable. The importance of this measure is that, if unemployment falls below its NAIRU rate, inflation will accelerate, whilst if above the NAIRU, inflation will fall.

Optimum Currency Area (OCA) Theory This theory is utilised by economists to identify those factors which indicate the optimum size of a currency arrangement. Consequently, the theory proposes that objective tests can be employed to decide whether it is in the common interests of, for example, Ireland and Italy, or France and Germany, as to whether they should join together in the eurozone, or whether it is to their mutual advantage to retain separate currencies and monetary systems. Similarly, the theory could be used to identify whether regions, rather than countries, should form a currency union. In practice, however, whilst nation states remain the principal form of government for the majority of the world's population, OCA theory will be concerned in deciding where monetary integration should and should not be formed between groups of countries.

Single European Act (SEA) The 1986 Single European Act introduced the single internal market, but also extended qualified majority voting within the Council of Ministers and further committed the EU to 'the objective of the progressive realisation of European and Monetary Union'.

Single Internal Market (SIM) Resulting from the 1986 Single European Act, the single market refers to the removal of trade, capital and physical barriers across Europe, supposedly achieved by 1 January 1993, which allows free competition across the entire EU market.

Stability and Growth Pact (SGP) Proposed by Germany to avoid excessive fiscal profligacy by individual member states within the eurozone, it limits budget deficits to 3\% of GDP (as per TEU convergence criteria prior to membership). If this limit is ignored, and the country is not in recession (defined as GDP falling by $0.75 \%$ ), fines of between 0.2 and $0.5 \%$ of GDP will be levied by the EU financial authorities. The Stability and Growth Pact additionally suggests that budget deficits be limited to $1 \%$ of GDP in the long term, thus increasing fiscal tightening. 